\title{
Blood Brain Barrier (Bbb) Role in Delivering the Chemotherapeutic Agents to the Brain in the Treatment of Brain Tumors
}

\author{
Behzad Saberi* \\ Medical Research, Esfahan, Iran
}

Submission: August 27, 2019; Published: September 26, 2019

${ }^{*}$ Correspondence Author: Behzad Saberi, Medical Research, Esfahan, Iran

\section{Mini Review}

Systemic chemotherapy would be challenging to treat brain tumors. Achieving the required concentrations of the chemotherapeutic agents in the brain would be influenced by some factors like the volume of distribution of the agent in the brain parenchyma, the ability of the agent to cross the blood brain barrier and active amount of the drug which can be transported out of the brain. Because of difficulties to reach the specific sites of the brain, drug delivering in systemic chemotherapy for brain tumors would encounter various failures [1]. Also, there are other barriers which influence drug delivering to the brain including blood-cerebrospinal fluid barrier, brain-cerebrospinal fluid barrier and the brain tumor barrier. A monolayer of brain capillary endothelial cells is the main part of the blood brain barrier. The interaction between endothelial and astrocyte cells and the tight junctions between endothelial cells, restrict the brain penetration by the chemotherapeutic agents [2]. Lacking intercellular fenestrations and having low ionic permeability and high electrical resistance in the endothelial cells of brain capillaries, make many of water-soluble agents to be unable to reach the brain.

Passive diffusion or catalyzed transportation via lipidmediated transportation of small and nonpolar molecules, would be the main route of crossing the blood brain barrier by the compounds. up taking across the blood-facing membrane into the endothelial cells and then transporting through the transcellular membrane and effluxion through the parenchymafacing membrane into the interstitial fluid, are the factors which make reaching the brain parenchyma by the agent,

successful [3]. Enough drug delivering to the tumor cells and the tumor-infiltrated brain parts located around the tumor, makes chemotherapy for brain tumors successful. Lipid solubility, having sizes less than 200 daltons, being minimally ionized and not being bound to plasma proteins are the factors which make chemotherapeutic agents, effective to treat brain tumors in systemic administration routes. Potential use of some agents like mannitol and bradykinin analogues to increase drug delivery to brain tumors, needs more studies to be done to be approved and be employed in chemotherapy for brain tumors $[4,5]$.

\section{References}

1. Zhang RD, Price JE, Fujimaki T, Bucana CD, Fidler IJ (1992) Differential permeability of the blood-brain barrier in experimental brain metastases produced by human neoplasms implanted into nude mice. Am J Pathol 141(5): 1115-1124.

2. Ott RJ, Brada M, Flower MA, Babich JW, Cherry SR, et al. (1991) Measurements of blood-brain barrier permeability in patients undergoing radiotherapy and chemotherapy for primary cerebral lymphoma. Eur J Cancer 27(11): 1356-1361.

3. Fortin D, Desjardins A, Benko A, Niyonsega T, Boudrias M (2005) Enhanced chemotherapy delivery by intraarterial infusion and bloodbrain barrier disruption in malignant brain tumors: the Sherbrooke experience. Cancer 103(2): 2606-2615.

4. Knudsen GM, Pettigrew KD, Patlak CS, Hertz MM, Paulson OB (1990) Asymmetrical transport of amino acids across the blood-brain barrier in humans. J Cereb Blood Flow Metab 10(5): 698-706.

5. Remsen LG, McCormick CI, Sexton G, Pearse HD, Garcia R, et al. (1995) Decreased delivery and acute toxicity of cranial irradiation and chemotherapy given with osmotic blood-brain barrier disruption in a rodent model: the issue of sequence. Clin Cancer Res 1(7): 731-739. 


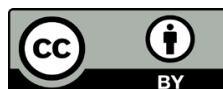

This work is licensed under Creative Commons Attribution 4.0 License DOI: 10.19080/CTOIJ.2019.15.555903

\section{Your next submission with Juniper Publishers} will reach you the below assets

- Quality Editorial service

- Swift Peer Review

- Reprints availability

- E-prints Service

- Manuscript Podcast for convenient understanding

- Global attainment for your research

- Manuscript accessibility in different formats ( Pdf, E-pub, Full Text, Audio)

- Unceasing customer service

Track the below URL for one-step submission https://juniperpublishers.com/online-submission.php 